\title{
The antibacterial activity, antioxidant activity and selectivity index of leaf extracts of thirteen South African tree species used in ethnoveterinary medicine to treat helminth infections
}

\author{
Mathew Adamu ${ }^{1,2}$, Vinny Naidoo ${ }^{1}$ and Jacobus N Eloff ${ }^{*}$
}

\begin{abstract}
Background: Diseases caused by bacteria remain a major challenge globally and particularly in sub-Saharan Africa. The plants used in this study have been used in South Africa to treat helminth infections in livestock and humans. In a previous study we found a correlation between antifungal and anthelmintic activity in some cases. In this study we examined other potential uses of these thirteen plant species by determining the antibacterial and antioxidant activity of the leaf acetone extracts.

The antibacterial activity was determined by using a serial microdilution method against Staphylococcus aureus, Pseudomonas aeruginosa, Escherichia coli and Enterococcus faecalis. Bioautography was used to determine the number of antibacterial compounds. The antioxidant activity was determined using the ABTS and DPPH methods.

Results: Maesa lanceolata and Leucosidea sericea with an MIC of $0.02 \mathrm{mg} / \mathrm{ml}$ had excellent antibacterial activity against Enterococcus faecalis and Pseudomonas aeruginosa. There was a poor correlation between antioxidant activity and antibacterial activity with $R^{2}=0.143$. This is because antibacterial activity is mainly related to non-polar compounds and antioxidant activity to polar compounds. Maesa lanceolata extracts had a low cytotoxicity with a selectivity index of 5.2, 2.6, 2.6 and 1.3 for P. aeruginosa, E. faecalis, E. coli and S. aureus respectively. Strychnos mitis extracts had a therapeutic index of 1.1 for E. coli.
\end{abstract}

Conclusions: This study shows that plant extracts of some species used in ethnoveterinary medicine as anthelmintic may also have excellent antibacterial activity.

\section{Background}

Resistance to available antibiotics is increasing at a very alarming stage globally [1]. Efforts are urgently needed to replace current available antibiotics. This resistance is complex especially in sub-Saharan Africa due to the incidence of HIV/AIDS and diseases such as tuberculosis decreasing the immune activity of hosts. The situation is complicated by poor sanitary conditions and poor access to potable water mainly due to poverty. If antibiotics are available they are too expensive for the poorer communities. In some cases especially in the rural areas antibiotics are adulterated and of little value in the treatment

\footnotetext{
*Correspondence: kobus.eloff@up.ac.za

'Phytomedicine Programme, Department of Paraclinical Sciences, Faculty of Veterinary Science, University of Pretoria, Private Bag X04, Onderstepoort, Pretoria 0110, South Africa

Full list of author information is available at the end of the article
}

of diseases caused by bacteria to humans and animals [2]. The antibacterial activity of plants is continuously attracting global attention [3,4]. Parasitic infection may lead to the release of free radicals which may have severe consequences on cellular metabolism. The anthelmintic activity may therefore be due to the presence of antioxidants in extracts that have the potential to prevent the activity of free radicals and reactive oxygen species thus helping in fighting diseases caused by bacteria and other pathogens.

South Africa with $10 \%$ of the vascular plant species diversity of the world is a potential source of undiscovered compounds with high activity of extracts against a variety of bacterial and fungal pathogens [5]. The plant species used in this study were chosen based on evidence of traditional use as anthelmintics and antibacterial as well 
as availability. This investigation will assist in identifying plants for further study aimed at identifying compounds as potential source of new antibiotic for primary health care needs of man and his animals. If plant extracts that have anthelmintic activity are also useful in combating bacterial pathogens it could have a double value.

These plants were originally investigated for its activity against Haemonchus contortus a very important helminth of sheep. Some of the extracts had promising activity [6]. There were also promising activity against certain important fungal pathogens [7]. Some of these extracts had a potential to be used to treat animal diseases caused by fungi or helminths. It will be interesting to determine the potential use against bacteria and also the degree to which some of these extracts would have antioxidant activity that could address inflammations caused by microbes or helminths. The aim of this study therefore was to determine the antibacterial and antioxidant activity of thirteen selected tree species against two Gram-positive and two Gram-negative bacteria. A secondary aim was to calculate the selectivity index (also known as therapeutic index) of these extracts in combating bacteria. One of the parameters that plays a role in selecting the best plant species for development of a product is the total activity. By dividing the mass in $\mathrm{mg}$ extracted from $1 \mathrm{~g}$ of plant material with the MIC in $\mathrm{mg} / \mathrm{ml}$ a value is obtained that indicates to what level the active compounds in $1 \mathrm{~g}$ of plant material can be diluted and still retain the activity against the pathogen.

\section{Methods}

Plant collection

Leaves of thirteen plant species were collected in November 2009 at the Pretoria National Botanical Garden in South Africa. The trees were identified and labeled and voucher specimens were made and stored in the HGW Schweickert Herbarium of the University of Pretoria with voucher numbers (Table 1). The leaves were dried at room temperature in a ventilated room, milled to a fine powder in Macsalab Mill (Model 2000 LAB Eriez ${ }^{\circ}$ and stored in closed containers in the dark until use.

\section{Plant extraction}

Plant material from each species investigated was extracted with acetone, (technical grade, Merck) in polyester centrifuge tubes at a ratio of $10 \mathrm{ml} / \mathrm{g}$ and repeated twice. Acetone was selected based on its superiority as extractant based on a number of parameters [17] especially because it extracts compounds with a wide range of polarities and has low toxicity to humans and to microorganisms. The tubes were vigorously shaken for $30 \mathrm{~min}$ on an orbital shaker. Tubes were centrifuged at $4000 \mathrm{x} \mathrm{g}$ for $10 \mathrm{~min}$ and the supernatant was filtered using Whatman No.1 filter paper before being transferred into pre-weighed glass containers. Acetone was evaporated under a stream of air in a fume hood at room temperature to produce the dried extract and for quantification [18].

\section{Chromatographic analysis}

The extracted chemical components were analysed by separation with thin layer chromatography (TLC) using aluminium-backed TLC plates (Merck, Silica gel F254). The TLC plates were developed in saturated chambers using mobile phases of varying polarities, namely, ethyl acetate/methanol/water (40:5.4:5) [EMW] (polar/neutral), chloroform/ethyl acetate/formic acid (5:4:1) [CEF] (intermediate polarity/acidic) and benzene/ethanol/ammonia hydroxide (90:10:1) [BEA] (non-polar/basic) [19].

Table 1 List of plant species used in the investigation, their traditional uses and references

\begin{tabular}{|c|c|c|c|}
\hline Plant species & Family & Medicinal uses & Reference \\
\hline Brachylaena discolor & Asteraceae(267) & Purgatives against intestinal parasites, anthelmintics for calves, sheep and goats & {$[8-10]$} \\
\hline Zanthoxylum capense & Rutaceae(96) & Gastric and intestinal disorders, anthelmintics, cough, bronchitis, pleurisy & {$[8,10]$} \\
\hline Clerodendrum glabrum & Lamiaceae(403) & Intestinal parasites, coughs, fever and diabetes & {$[8-10]$} \\
\hline Heteromorpha trifoliata & Apiaceae(491) & Intestinal worms, colic in horses and vermifuge, enemas for abdominal disorders & {$[8,9,11]$} \\
\hline Apodytes dimidiata & Icacinaceae(139) & Enemas for intestinal parasites, purgatives, inflammation of the ear & {$[8,9,11]$} \\
\hline Strychnos mitis & Strychnaceae(73) & Malaria, fevers & [12] \\
\hline Maesa lanceolata & Maesaceae(615) & Anthelmintics, treatment of wounds and infertility & [9] \\
\hline Indigofera frutescens & Papilionaceae(675) & Anthelmintics & [9] \\
\hline Leucosidea sericea & Rosaceae(288) & Treatment of opthalmia, anthelmintics, astringents and vermifuge & {$[9,13]$} \\
\hline Melia azedarach & Meliaceae(702) & Effective anthelmintics, emetic, cathartic and treatment of eczema & {$[9,10,14]$} \\
\hline Clausena anisata & Rutaceae(317) & Anthelmintics, purgatives, rheumatism, fevers and myiasis & [15] \\
\hline Cyathea dregei & Cyatheaceae(658) & Anthelmintics & [15] \\
\hline Millettia grandis & Papilionaceae(704) & Anthelmintics and tranquilizers & {$[9,16]$} \\
\hline
\end{tabular}

Only the leaves of these plants species were used in the study. Figures in brackets after family name are PRU voucher specimen numbers. (Table from Adamu et al., [6]). 
Separated compounds were visualised under UV light at wavelengths of 254 and $365 \mathrm{~nm}$ after which TLC plates were sprayed with vanillin-sulphuric acid and heated at $110^{\circ} \mathrm{C}$ for optimal colour development [20].

\section{Antioxidant activity}

Antioxidant activity was determined by using qualitative and quantitative methods. For the qualitative antioxidant activity TLC chromatograms of extracts were sprayed with 0.2\% 1, 1-diphenyl-2-picryl-hydrazyl (DPPH) (Sigma) in methanol as an indicator [21]. The quantitative antioxidant activities were determined using the ABTS (2,2' -azinobis-(3-ethylbenzothiazoline-6-sulfonic acid) and DPPH methods [22,23]. These methods compare the antioxidant activity of the extracts to that of the standards ABTS and $\mathrm{DPPH}$ by measuring the decolorization of extracts spectrophotometrically. The $\mathrm{EC}_{50}$ values for the $\mathrm{DPPH}$ analysis was determined by plotting activity against concentration and determining which concentration would have yielded an activity of $50 \%$.

\section{Antibacterial activity}

The MIC values were determined using a serial microplate dilution method [24]. Bacterial organisms used were Staphylococcus aureus (ATCC 29213), Enterococcus faecalis (ATCC 29212), Pseudomonas aeruginosa (ATCC 27853) and Escherichia coli (ATCC 25922). These strains are recommended for antibacterial activity testing by the United States National Committee for clinical laboratory standards [25]. Bacterial cells were inoculated into fresh Müller-Hinton $(\mathrm{MH})$ broth (Fluka, Switzerland) and incubated at $37^{\circ} \mathrm{C}$ overnight and density determined prior to the screening procedures. Densities of bacterial cultures after incubation overnight were diluted to the following:: Staphylococcus aureus, $2.6 \times 10^{12} \mathrm{cfu} / \mathrm{ml}$; Enterococcus faecalis, $1.5 \times$ $10^{10} \mathrm{cfu} / \mathrm{ml}$; Pseudomonas aeruginosa, $5.2 \times 10^{13} \mathrm{cfu} / \mathrm{ml}$; Escherichia coli, $3.0 \times 10^{11} \mathrm{cfu} / \mathrm{ml}$. One of the key aspects are that a $50 \%$ inoculum was used, this led to enhanced growth with no lag phase and eliminated possible complications due to infections by spores of other microorganisms [24]. Acetone was used as solvent control, while gentamicin was the positive drug control.

\section{Bioautographic investigations}

Bioautography is a specialized form of planar chromatography where the separated compounds are not made visible by treating with a spray reagent but are sprayed with a live microorganism, incubated and then sprayed with a chemical that indicates whether the microorganism grew or not. This makes it possible to determine how many different antimicrobial compounds were separated and also to calculate the $R_{f}$ value of the bioactive compounds. Thin layer chromatography (TLC) plates were loaded with $10 \mu \mathrm{l}$ of $10 \mathrm{mg} / \mathrm{ml}$ of extract and dried before developing in mobile phases of BEA, CEF and EMW. The solvents were completely evaporated from the plates in a stream of air. Plates were then sprayed with concentrated cultures of bacteria until completely moist using a spraying gun coupled to an air pump. The moist plates were incubated overnight at $37^{\circ} \mathrm{C}$ in a sealed container in an incubator under $100 \%$ relative humidity. The plates were then sprayed with $2 \mathrm{mg} / \mathrm{ml}$ of $p$-iodonitrotetrazolium violet (INT) (Sigma) and incubated for a further $2 \mathrm{~h}$ or until clear growth was apparent [26]. The emergence of purple-red colour resulting from the reduction of INT into its respective formazan was a positive indicator of cell viability [26]. Clear zones against the purple background indicated antibacterial activity of compounds separated on the chromatogram.

\section{Results}

\section{Plant extracts yield}

Leaves of the thirteen plant species were extracted using acetone as the extracting solvent, this gave different percentage yields(Table 2), with Leucosidea sericea having the highest yield of $6.3 \%$, (6.3 mg extracted out of every $100 \mathrm{mg}$ dried leaf material) followed closely by Apodytes dimidiata with $6.1 \%$. The lowest yield was obtained with Zanthoxylum capense (0.8\%).

\section{Phytochemical profiling and antioxidant activity}

Extracts of plants contain many chemical compounds (7). The compounds varied from polar to non-polar and in some extracts compounds of intermediate polarity were observed (Figure 1). Maesa lanceolata (ML) had

Table 2 Percentage yield and antioxidant activity of thirteen South African plant extracts used for antibacterial activity

\begin{tabular}{llll}
\hline Plant species & \% Yield & EC $_{\text {50 }}$ DPPH & TEAC \\
\hline Heteromorpha trifoliata & 3.3 & 4.36 & 0.2 \\
Indigofera frutescens & 0.8 & 0 & 0.5 \\
Zanthoxylum capense & 1.6 & 4.0 & 0.4 \\
Milletia grandis & 1.3 & 4.6 & 0.6 \\
Brachylaena discolor & 6.1 & 2.6 & 0.2 \\
Clerodendrum glabrum & 3.8 & 3.5 & 0.5 \\
Strychnos mitis & 2.8 & 3.5 & 0.3 \\
Cyathea dregei & 2.1 & 3 & 0.4 \\
Apodytes dimidiata & 6.3 & 3.5 & 0.3 \\
Melia azedarach & 2.3 & 3.3 & 0.8 \\
Clausena anisata & 3.4 & 2.5 & 0.2 \\
Maesa lanceolata & 2.5 & 1.4 & 1.2 \\
Leucosidea sericea & 1.2 & 0.0 & 0.7 \\
\hline
\end{tabular}

$\mathrm{EC}_{50}$ concentration that leads to $50 \%$ reduction in DPPH activity (the lower the value the higher the activity), TEAC Trolox equivalent antioxidant assay. Activity compared to trolox (the higher the value the higher the activity). 


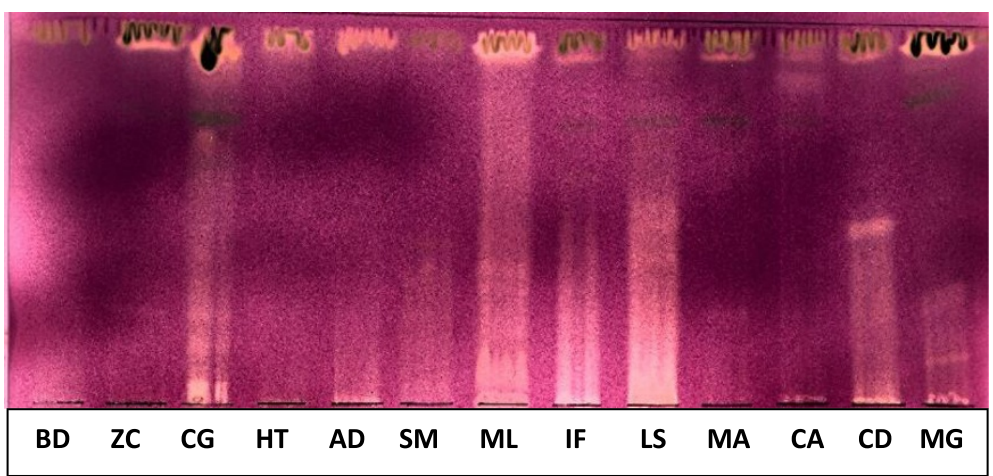

Figure 1 Chromatogram developed with EMW and sprayed with DPPH. Yellow bands indicate separated compounds with antioxidant activity KEY: BD, Brachylaena discolor; ZC, Zanthoxylum capense; CG, Clerodendrum glabrum; HT, Heteromorpha trifoliata; AD, Apodytes dimidiata; SM, Strychnos mitis; ML, Maesa lanceolata; IF, Indigofera frutescens; LS, Leucosidea sericea; MA, Melia azedarach; CA, Clausena anisata; CD, Cyathea dregei; MG, Milletia grandis.

the most antioxidant compounds (Figure 1) followed by L. sericea (LS). This pattern was consistent in all 3 solvent systems (BEA, EMW and CEF) used and was supported by the ABTS and DPPH assays used for quantification of the antioxidant activity (Table 2). M. lanceolata with a TEAC of 1.20 and $L$. sericea with an $\mathrm{EC}_{50}$ of 0.0051 had the best antioxidant activity using ABTS and DPPH respectively.

\section{Bioautography}

Three solvent systems were used. The non-polar BEA separated $56 \%$ of the total active bands against the four bacteria indicating that the antibacterial compounds were non-polar. The position of active compounds on the chromatogram relative to the front $\left(R_{f}\right)$ should be consistent under similar conditions and is calculated by dividing the distance the compound travelled with the distance of the front of the eluent. The highest number of active bands was in the L. sericea extract separated with BEA, (Figure 2) with 6 active bands against $E$. coli $\left(\mathrm{R}_{\mathrm{f}}\right.$ values; $2.35,2.67$, $2.86,3.20,3.48$ and 4.0 ) and M. lanceolata with 4 active bands ( $\mathrm{R}_{\mathrm{f}}$ values; 1.07, 2.29, 2.67 and 4.00). S. mitis had one active band $\left(R_{f} 1.22\right)$ in BEA solvent against $S$. aureus. A compound with $R_{f}$ value of 4.00 was active in Zanthoxylum capense (2.11, 4.00), Clerodendrum glabrum (4.00), Heteromorpha trifoliata (4.0), Maesa lanceolata, Indigofera frutescens (2.00, 4.00), Leucosidea sericea, Melia azedarach (2.00, 4.00), Clausena anisata (1.14, 4.00) and Milletia grandis $(2.00,3.48,4.00)$. This may mean that the same antibacterial compound is present in extracts of nine species. The 13 plant extracts had more active bands against $E$. coli than other tested organisms. In total, 75 active bands were recorded against the four bacteria.

\section{Minimal inhibitory concentrations and total activity against bacterial pathogens}

The minimal inhibitory concentration (MIC) for the antibacterial activity of the leaf extracts and cytotoxicity of the plant extracts are presented in Tables 3 and 4. $L$. sericea and M. lanceolata extracts with MIC of 0.02 $\mathrm{mg} / \mathrm{ml}$ against $E$. faecalis and $P$. aeruginosa were the best for this study. This was followed by $0.04 \mathrm{mg} / \mathrm{ml}$ for M. lanceolata against $P$. aeruginosa and $0.08 \mathrm{mg} / \mathrm{ml}$ for

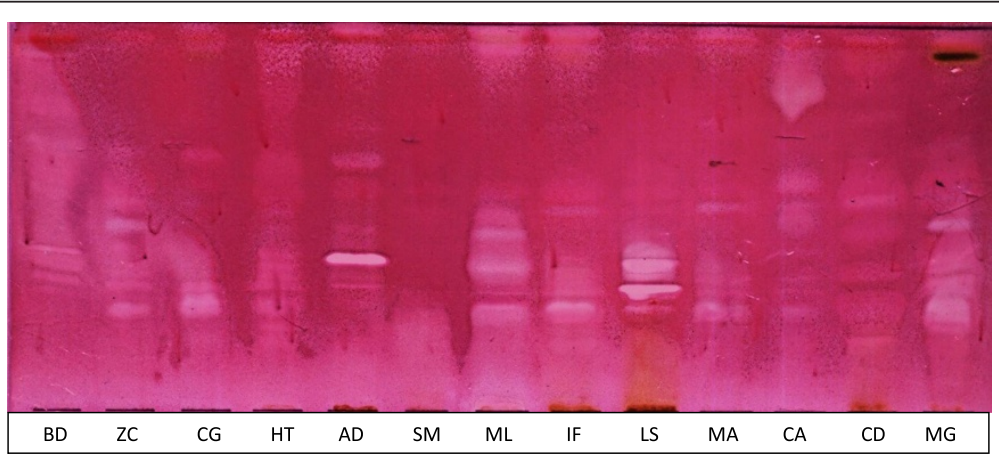

Figure 2 Bioautogram developed with BEA of different plant leaf acetone extracts against $E$. coli showing antibacterial bands. White bands indicate separated compounds that inhibited the growth of E. coli KEY. BD, Brachylaena discolor; ZC, Zanthoxylum capense; CG, Clerodendrum glabrum; HT, Heteromorpha trifoliata; AD, Apodytes dimidiata; SM, Strychnos mitis; ML, Maesa lanceolata; IF, Indigofera frutescens; LS, Leucosidea sericea; MA, Melia azedarach; CA, Clausena anisata; CD, Cyathea dregei; MG, Milletia grandis. 
Table 3 Minimal inhibitory concentrations (MIC) (lowest concentration that inhibits the growth of the pathogen) in $\mathrm{mg} / \mathrm{ml}$ of the leaf extracts of 13 plant species evaluated for antibacterial activity using four bacteria organisms

\begin{tabular}{lllll}
\hline Plant species & S. aureus & E. coli & E. faecalis & P. aeruginosa \\
\hline Brachylaena discolor & 1.25 & 0.63 & 0.16 & 0.31 \\
Zanthoxylum capense & 1.25 & 2.50 & 0.31 & 0.31 \\
Clerodendrum glabrum & 1.25 & 0.31 & 1.25 & 0.63 \\
Heteromorpha trifoliata & 1.25 & 0.63 & 1.25 & 0.63 \\
Apodytes dimidiata & 0.31 & 2.50 & 1.25 & 0.31 \\
Strychnos mitis & 0.31 & 0.04 & 0.63 & 0.16 \\
Maesa lanceolata & 0.08 & 0.04 & 0.04 & 0.02 \\
Indigofera frutescens & 0.16 & 0.16 & 0.08 & 0.31 \\
Leucosidea sericea & 0.08 & 0.08 & 0.02 & 0.02 \\
Melia azedarach & 0.63 & 0.31 & 0.16 & 0.63 \\
Clausena anisata & 0.16 & 0.31 & 0.31 & 0.31 \\
Cyathea dregei & 0.31 & 0.31 & 1.25 & 0.31 \\
Milletia grandis & 0.31 & 0.31 & 0.31 & 0.31 \\
Gentamicin & $<0.02$ & $<0.02$ & $<0.02$ & $<0.02$ \\
Acetone & $>25 \%$ & $>25 \%$ & $>25 \%$ & $>25 \%$ \\
\hline
\end{tabular}

L. sericea and M. lanceolata against S. aureus, E. coli and $S$. aureus respectively. Other plant extracts with good MIC values were C. anisata, I. frutescens, B. discolor and M. azedarach with MIC of $0.16 \mathrm{mg} / \mathrm{ml}$. The other plant extracts had moderate MIC values with the exception of $Z$. capense and A. dimidiata with poor MIC values as high as $2.5 \mathrm{mg} / \mathrm{ml}$. There is some consensus that MIC values of $0.10 \mathrm{mg} / \mathrm{ml}$ or less are considered good $(18,24)$ while values up to $0.32 \mathrm{mg} / \mathrm{ml}$ are reasonable. MIC values above 0.64 are considered as having poor activity. Pseudomonas aeruginosa and Enterococcus faecalis were the most susceptible bacteria organisms among the bacteria tested.

Total activity depends not only on the antibacterial activity of the extract, but also on the quantity extracted from the plant. $L$. sericea had the best total activity of $6265 \mathrm{ml} / \mathrm{g}$ against $P$. aeruginosa and $E$. faecalis (Table 5). This means that the extract from one gram of the plant material could be diluted to $6265 \mathrm{ml}$ and still retains activity against the microorganism. The two plants extracts with the lowest total activity value were $Z$. capense and $H$. trifoliata with 6.5 and $13 \mathrm{ml} / \mathrm{g}$ respectively.

\section{Discussion}

In general extracts with a good antioxidant activity (low $\mathrm{EC}_{50}$ or high TEAC) had a low antibacterial (high MIC) activity. The correlation coefficient between MIC and DPPH was 0.0118 and between MIC and TEAC was 0.0068 . We have frequently found that nonpolar extracts or compounds from plant extracts had high antibacterial activity and polar compounds had low antibacterial activity. In the case of $L$. sericea and $M$. lanceolata we found good antioxidant activity with TEAC values of 0.7 and 1.2 and good antimicrobial activity (MIC $0.04 \mathrm{mg} / \mathrm{ml}$ for all four bacteria). It is possible that these extracts may contain tannins that are known to have good antioxidant and antibacterial activity. The results show that plants extracts are active against both Gram positive and Gram negative bacteria. It has frequently been stated that plant extracts are more active against Gram positive bacteria than against Gram negative bacteria [27]. This may be due to the cell walls of Gram negative bacteria

Table 4 Cytotoxicity from Adamu et al., [6] and selectivity index of leaf acetone extracts of 13 plant species against four bacterial pathogens calculated by dividing cytotoxicity by MIC

\begin{tabular}{|c|c|c|c|c|c|}
\hline Plant species & Cytotoxicity (mg/ml) & Staphylococcus aureus & Escherichia coli & Enterococcus faecalis & Pseudomonas aeruginosa \\
\hline Brachylaena discolor & 0.004 & 0.00 & 0.01 & 0.03 & 0.01 \\
\hline Zanthoxylum capense & 0.008 & 0.01 & 0.00 & 0.03 & 0.03 \\
\hline Clerodendrum glabrum & 0.172 & 0.14 & 0.55 & 0.14 & 0.27 \\
\hline Heteromorpha trifoliata & 0.043 & 0.03 & 0.07 & 0.03 & 0.07 \\
\hline Apodytes dimidiata & 0.003 & 0.01 & 0.00 & 0.00 & 0.01 \\
\hline Strychnos mitis & 0.043 & 0.14 & 1.08 & 0.07 & 0.27 \\
\hline Maesa lanceolata & 0.104 & 1.30 & 2.60 & 2.60 & 5.20 \\
\hline Indigofera frutescens & 0.052 & 0.33 & 0.33 & 0.65 & 0.17 \\
\hline Leucosidea sericea & 0.016 & 0.20 & 0.22 & 0.80 & 0.80 \\
\hline Melia azedarach & 0.145 & 0.23 & 0.47 & 0.91 & 0.23 \\
\hline Clausena anisata & 0.053 & 0.33 & 0.17 & 0.17 & 0.17 \\
\hline Cyathea dregei & 0.017 & 0.05 & 0.05 & 0.01 & 0.05 \\
\hline Milletia grandis & 0.021 & 0.07 & 0.07 & 0.07 & 0.07 \\
\hline
\end{tabular}




\begin{tabular}{|c|c|c|c|c|}
\hline Plant species & $\begin{array}{c}\text { Staphylococcus } \\
\text { aureus }\end{array}$ & $\begin{array}{l}\text { Escherichia } \\
\text { coli }\end{array}$ & $\begin{array}{l}\text { Enterococcus } \\
\text { faecalis }\end{array}$ & $\begin{array}{c}\text { Pseudomonas } \\
\text { aeruginosa }\end{array}$ \\
\hline Brachylaena discolor & 52.8 & 104.8 & 412.5 & 213 \\
\hline Zanthoxylum capense & 13 & 6.5 & 52.3 & 52.3 \\
\hline Clerodendrum glabrum & 25.5 & 102.9 & 25.5 & 50.6 \\
\hline Heteromorpha trifoliata & 20.4 & 40.5 & 20.4 & 40.5 \\
\hline Apodytes dimidiata & 391.6 & 48.6 & 97.1 & 391.6 \\
\hline Strychnos mitis & 241.9 & 1875 & 119.1 & 468.8 \\
\hline Maesa lanceolata & 697.5 & 1395 & 1395.0 & 2790 \\
\hline Indigofera frutescens & 256.3 & 256.3 & 512.5 & 132.3 \\
\hline Leucosidea sericea & 1566.3 & 1566.3 & 6265.0 & 6265 \\
\hline Melia azedarach & 72.7 & 147.7 & 286.3 & 72.7 \\
\hline Clausena anisata & 424.4 & 219 & 219 & 219 \\
\hline Cyathea dregei & 161.3 & 161.3 & 40 & 161.3 \\
\hline Milletia grandis & 79.7 & 79.7 & 80 & 79.7 \\
\hline
\end{tabular}

being less permeable to antimicrobial compounds [28]. With the plant extracts used here the average antibacterial activity against the Gram negative bacteria was slightly better than the activity against Gram positive bacteria (MIC of 0.48 vs. $0.55 \mathrm{mg} / \mathrm{ml}$ ).

Based on the selectivity index, that is the ratio of MIC to cytotoxicity value, the $M$. lanceolata extract had the best selectivity index of 5.2. The results make such plant extracts good candidates for further study. The selectivity value helps to differentiate activity that is due to general toxicity and one that is selectively toxic to microorganisms.

Extracts of L. sericea and M. lanceolata had the best antibacterial activity with an MIC of $0.02 \mathrm{mg} / \mathrm{ml}$ in this study. Previous study by Bosman et al., [29] reported that $L$. sericea had activity against bacteria organisms using the disc diffusion method, but no activity was reported for acetone leaf extracts of $L$. sericea. This study does not agree with their findings. This is probably due to the different methods used. The microdilution method we used is more sensitive than the disc diffusion method [24]. Recently, Aremu et al., [30] reported an MIC of $0.025 \mathrm{mg} / \mathrm{ml}$ using petroleum ether and dichloromethane leaf extracts of $L$. sericea against Bacillus subtilis and Staphylococcus aureus. The solvent used in our study differed to that used in their study. With solvent known to extract compounds of different polarity from same plant, this may explain the different MIC values of $0.04 \mathrm{mg} / \mathrm{ml}$ for $\mathrm{S}$. aureus as compared to 0.025 $\mathrm{mg} / \mathrm{ml}$ by Aremu et al., [30]. The activity of $L$. sericea may be due to the presence of active compounds such as aspindinol [29], alkaloids, phenolics and saponins [30] that had previously been reported from this plant.
Maesa lanceolata had an MIC of $0.02 \mathrm{mg} / \mathrm{ml}$, this is the first report of such a good activity from this plant extract. Previous study by Sindambiwe et al., [31] reported that the plant extract did not have antibacterial activity even at high concentration of $10 \mathrm{mg} / \mathrm{ml}$. The results differ probably due to the method in use, as they used the agar dilution and broth dilution method for antibacterial and antifungal assays respectively. The poor antibacterial activity shown by $Z$. capense in this study agrees with past study by McGaw et al., [32].

The results of the bioautography correlates positively with the MIC results, for example $L$. sericea had 6 compounds in the BEA system, while M. lanceolata had 4 compounds and a corresponding MIC value of $0.04 \mathrm{mg} /$ $\mathrm{ml}$ as the best average MIC value for all four bacteria tested. Previously, report on the anthelmintic [6] and antifungal activity [7] of acetone extracts of these plant species have shown varied degree of activity. The most promising plant extracts against egg hatching and larval development of Haemonchus contortus were $H$. trifoliata, $M$. lanceolata and $L$. sericea. The most promising extracts based on activity against fungal pathogens were Clausena anisata, Clerodendrum glabrum, Milletia grandis and Zanthoxylum capense. The activity of L. sericea and $M$. lanceolata against bacterial pathogens in this study was the best. Based on the activity of these plant extracts against the eggs and larvae of $H$. contortus, bacteria, fungi and their cytotoxicity. Leucosidea sericea was selected for further study which involves activity guided fractionation and isolation of compounds of the most promising plants extracts and testing activity against egg and larvae of Haemonchus contortus, toxicity against Vero cell lines.

\section{Conclusions}

Some leaf extracts of plants used for anthelmintic purposes have good antibacterial activity or good antioxidant activity. It is possible that extracts with a good anthelmintic and antimicrobial activity may be active against a general metabolic system. If it had an effect on the Krebs cycle or electron transport chain, these extracts would also be toxic against animal cells. The selectivity index provides an indication of the safety of the extract. In the case of $L$. sericea and M. lanceolata the acetone extracts had promising activity, promising safety and with a total activity of higher than 1 litre/g also a very promising yield from tree leaves. In most cases the antioxidant activity was relatively low, This may mean that the effect on helminths is due to an effect on the worms and not on a general increase in the immune system of the host.

Competing interests

The authors declare that they have no competing interests. 


\section{Authors' contributions}

MA participated in the design of the study, carried out field work, prepared the extracts, participated in all assays and wrote the first draft of the manuscript. VN participated in the design and coordination of the study, supervised the study and revised the draft manuscript. JNE conceived the study, participated in the design and coordination of the study, supervised the study, analysed the data and revised the final manuscript. All authors read and approved the final manuscript.

\section{Acknowledgements}

University of Agriculture Makurdi and Tertiary Education Tax Fund (TETFund) Nigeria sponsored the study fellowship of MA, the National Research Foundation, South Africa, and the Faculty of Veterinary Science, University of Pretoria funded the work and granted MA a University of Pretoria research support bursary.

\section{Author details}

${ }^{1}$ Phytomedicine Programme, Department of Paraclinical Sciences, Faculty of Veterinary Science, University of Pretoria, Private Bag X04, Onderstepoort, Pretoria 0110, South Africa. ${ }^{2}$ Permanent Address: Department of Veterinary Parasitology and Entomology College of Veterinary Medicine, University of Agriculture Makurdi, Makurdi, Nigeria.

Received: 17 April 2013 Accepted: 11 February 2014

Published: 3 March 2014

\section{References}

1. Stuart BL, Bonnie M: Antibacterial resistance worldwide: causes, challenges and responses. Nat Med 2004, 10:S122-S129.

2. Isturiz RE, Carbon C: Antibiotic resistance in developing countries. Infect Control Hosp Epidemiol 2000, 21:394-397.

3. Rukayadi Y, Lee K, Han S, Yong D, Hwang J-K: In vitro activities of panduratin a against clinical staphylococcus strains. Antimicrob Agents Chemother 2009 53:4529-4533

4. Guzman JD, Gupta A, Evangelopoulos D, Basavannacharya C, Pabon LC, Plazas EA, Muñoz DR, Delgado WA, Cuca LE, Ribon W, Gibbons S, Bhakta S: Anti-tubercular screening of natural products from Colombian plants: 3-methoxynordomesticine, an inhibitor of MurE ligase of Mycobacterium tuberculosis. J Antimicrob Chemother 2010, 65:2101-2107.

5. Shai $L$, McGaw LJ, Masoko P, Eloff JN: Antifungal and antibacterial activity of seven traditionally used South African plant species active against Candida albicans. S Afr J Bot 2008, 74:677-684.

6. Adamu M, Naidoo V, Eloff JN: Efficacy and toxicity of thirteen plant leaf acetone extracts used in ethnoveterinary medicine in South Africa on egg hatching and larval development of Haemonchus contortus. BMC Complement Altern Med 2013, 9:38.

7. Adamu M, Naidoo V, Eloff JN: Some southern African plant species used to treat helminth infections in ethnoveterinary medicine have excellent antifungal activities. BMC Complement Altern Med 2013, 12:213.

8. Bryant AT: Zulu Medicine and Medicine-Men. Cape Town: C. Struik; 1966.

9. Watt JM, Breyer-Brandwijk MG: The Medicinal and Poisonous Plants of Southern and Eastern Africa. 2nd edition. London: Livingstone; 1962

10. Hutchings A, Scott AH, Lewis G, Cunningham AB: Zulu medicinal plants: an inventory. Pietermaritzburg: University of Natal Press; 1996

11. Gerstner J: A preliminary checklist of Zulu names of plants with short notes. In In bantu studies. 12th edition. Edited by George J, Liang MD, Drewes SE. Phytochemical Research in South Africa; 2001:215-236. S. Afr. J. Sci. 2001, 97: 93-105.

12. Bisset NG: The Asian species of Strychnos. Part III. The ethnobotany. Lloydia 1974, 37:62-107.

13. Jacot Guillarmod A: Flora of Lesotho. Lehr: Cramer; 1971

14. Oliver-Bever B: Anti-infective activity of higher plants. In Medicinal plants in tropical West Africa. Cambridge, UK: Cambridge University Press; 1986.

15. Doke CM, Vilakazi BW: Zulu-English dictionary. 2nd edition. Johannesburg: Witwatersrand University Press; 1972.

16. Palmer E, Pitman N: Trees of Southern Africa, Volume 3. Balkema: Cape Town Press; 1972.

17. Eloff $\mathrm{JN}$ : Which extractant should be used for the screening and isolation of antimicrobial components from plants? J Ethnopharmacol 1998, 60:1-8.

18. Eloff $\mathrm{JN}$ : Quantifying the bioactivity of plant extracts during screening and bioassay-guided fractionation. Phytomedicine 2004, 11:370-371.
19. Kotze M, Eloff JN: Extraction of antibacterial compounds from Combretum microphyllum (Combretaceae). S Afr J Bot 2002, 68:62-67.

20. Stahl E: Thin layer chromatography 2nd Ed. New York: Springer-Verlag; 1969

21. Deby C, Margotteaux G: Relationship between essential fatty acids and tissue antioxidant levels in mice. C R Seances Soc Biol Fil 1970, 165:2675-2681.

22. Re RP, Proteggente N, Pannala A, Yang A, Rice EC: Antioxidant activity applying an improved ABTS radical cation decolourazation assay. Free Radic Biol Med 1999, 26:1231-1237.

23. Brand WW, Cuvelier ME, Berset C: Use of a free radical method to evaluate antioxidant activity. Lebensmittel Wissenschaft und Technol 1995, 28:25-30.

24. Eloff JN: A sensitive and quick method to determine the minimum inhibitory concentration of plant extracts for bacteria. Planta Med 1998, 60:1-8.

25. National Committee for Clinical Laboratory Standards Performance Standards for Antimicrobial Susceptibility Testing: fourth information supplement. USA: Pennsylvania; 1990. NCCLS M100-S4.

26. Begue WJ, Kline RM: The use of tetrazolium salts in bioautographic procedures. J Chromatogr 1972, 64:182-184.

27. Vlietinck AJ, Van Hoof L, Totté J, Lasure A, Van den Berghe D, Rwangabo PC: Screening of hundred Rwandese medicinal plants for antimicrobial and antiviral properties. J Ethnopharmacol 1995, 46:31-47.

28. Hodges S: Pharmaceutical applications of microbiological techniques. In The science of dosage design. 2nd edition. Edited by Aulton ME. London: Harcourt Publishers Ltd; 2002:328-345.

29. Bosman AA, Combrinck S, Roux-van der Merwe P, Botha BM, McCrindle Rl: Isolation of an anthelmintic compound from Leucosidea sericea. $S$ Afr J Bot 2004, 70:509-511.

30. Aremu AO, Fawole OA, Chukwujekwu JC, Light ME, Finnie JF, Van Staden J: In vitro antimicrobial, anthelmintic and cyclooxygenase-inhibitory activities and phytochemical analysis of Leucosidea sericea. J Ethnopharmacol 2010, 131:22-27.

31. Sindambiwe JB, Calomme M, Cos P, Totte' J, Pieters L, Vlietinck A, Vanden $\mathrm{BD}$ : Screening of seven selected Rwandan medicinal plants for antimicrobial and antiviral activities. J Ethnopharmacol 1999, 65:71-77.

32. McGaw LJ, Jäger AK, Van Staden J: Antibacterial, anthelmintic and antiamoebic activity in South African medicinal plants. J Ethnopharmacol 2000, 72:247-263.

\section{doi:10.1186/1746-6148-10-52}

Cite this article as: Adamu et al:: The antibacterial activity, antioxidant activity and selectivity index of leaf extracts of thirteen South African tree species used in ethnoveterinary medicine to treat helminth infections. BMC Veterinary Research 2014 10:52

\section{Submit your next manuscript to BioMed Central and take full advantage of:}

- Convenient online submission

- Thorough peer review

- No space constraints or color figure charges

- Immediate publication on acceptance

- Inclusion in PubMed, CAS, Scopus and Google Scholar

- Research which is freely available for redistribution 